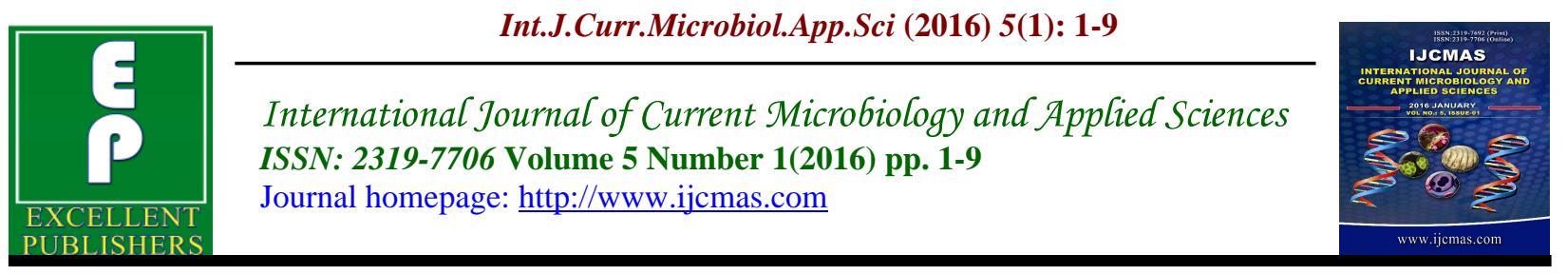

Original Research Article doi: hittp:///dx.doi.org/10.20546/ijcmas.2016.501.0001

\title{
Evaluation of Novel Immunological Mediator in Patients With Helicobacter pylori in Baghdad City, Iraq
}

\author{
Thamer Mutlag Jasim* \\ Department of Laboratory Clinical Sciences, College of Pharmacy, \\ All Mustansiriya University, Baghdad, Iraq \\ *Corresponding author
}

\begin{abstract}
A B S T R A C T
Keywords

H.pylori,

Cag A-IgG,

Fetuin A,

IL-6,

MCP1

Article Info

Accepted:

07 December 2015

Available Online:

10 January 2016

Helicobacter pylori (H.pylori) infection is endemic in Iraq and important cause of gatrointestinal disorders, as well as an increase in blood levels of certain inflammatory markers. Sixty patients infected with H.pylori was inserted in the current study with age (31.4 \pm 3.96$)$ randomly selected from Al Yarmok of Teaching Hospital in Baghdad during April 2015. Patients were diagnosed by using stool antigen and CagAIgG. The medical history was taken, body weight and height were measured and body mass index (BMI) was calculated. Serum Monocyte chemoattractant protein 1 (MCP1) was determined, as well as Interleukin 6 (IL-6) and Fetuin A levels. For comparison, thirty apparently healthy subjects which were matched with patients group for age, weight and BMI $(\mathrm{n}=30$, age $=30.5 \pm 3.77$ years; $\mathrm{BMI}=27.13 \pm 2.13 \mathrm{~kg} / \mathrm{m} 2$; mean $\pm \mathrm{SD})$. The prevalence of anti H.pylori $\mathrm{Cag} \mathrm{A}-\mathrm{IgG}$ antibodies in patient group $(78.3 \pm 9.8 \mathrm{U} / \mathrm{ml})$ significantly higher $(<0.0001)$ than healthy subjects group $(4.2 \pm 2.8 \mathrm{U} / \mathrm{ml})$. H.pylori was capable with a significant rise in the in the inflammatory mediators (fetuin A, MCP1 and IL-6). Fetuin A levels were very highly significant lower $(\mathrm{p}<0.0001)$ in patient, group when compared to healthy subjects $(29.53 \pm 5.25$ vs $53.45 \pm 8.37$ respectively). The MCP1 levels which significantly increased $(\mathrm{p}<0.0001)$ in patient group $(48.79 \pm 6.03)$ when compared to control group (37.2 \pm 6.85$)$. The mean of IL-6 also shown highly significant difference in patient group when compared to healthy control. The current study also shown there was a positive correlation between MCP1 and IL-6.
\end{abstract}

\section{Introduction}

Helicobacter pylori (H.pylori) is a highly adapted gastric pathogen that chronically infects more half of the world population (AminTalibi, 2014). H.pylori are gram negative, microaerophilic that colonize the stomach gastritis adenocarcinoma and peptic ulcer (Davand et al., 2013,Fischer et al., 2009).The Cag A gene, which is the marker for the presence of pathogenicity is land has been shown to be involved induction of proinflammatory cytokine release (Nader Baghert et al., 2015).

The secretion of chemokines is an important 
part of the host defence against invading pathogen, however, they may also contribute to pathogenesis of disease by promoting mucosal damage and epithelial dysfunction for example, intestinal metaplasia may be induced by cytokines for promoting persistant epithelial cell activation and intracellular signaling(Crabter 1998). Monocyte Chemoattractant Protein-1 (MCP1) may induce release of oxygen-free radical and proteases from inflammatory cell causing organ damage and fauilure (Klier et al.,2001). Biological factors that affect clinical outcome in H.pylori infection virulence determinant in H.pylori strains, immunological factors in the host are likely to play crucial role, clinical expression mucosa is related to increased production of proinflammatory cytokines, including IL-6 which are believed to contribute to maintaining the gastric inflammation and causing epithelial cell damage(Zandi et al., 2013). IL-6 is acytokine with awide variety of biological functions. This is a potent inducer of the acute face response. IL-6 plays an essential role in find differentiation of $\mathrm{B}$ cell into log-secreting cells involved in lymphocyte and monocyte differentiation. H.pylori infection secreted various cytokines, including MCP1 and thus induced $\mathrm{T}$ cell cox- 2 expression and activity. Fetuin A inhibit insulin receptor tyrosine activity by blooking autophosphorelation of tyrosinnase and IRS-1 induce lower grade inflammation (A.M.Hennige et al.,2008). Many studies have shown that H.pylori infection elevated production of proinflammatory cytokines,regulators of immune and some peptide chemokines such as interleukin 6 (Arabi 2010). The aim of the present study to investigate the relationship of mediator CagA-IgG, MCP-1,IL-6 and Fetuin A among H.pylori infection.

\section{Material and Methods}

Sixty patients infected with H.pylori was inserted in the current study with age (31.4 \pm 3.96$)$ randomly selected from those attending Al-Yarmook Teaching Hospital in Baghdad during April in 2015. Patients were diagnosed by using stool Ag test (Coris-Bio, BELGIUM). Another test also done -Cag-A IgG (Biocompare,USA) to support the diagnosis. The medical history was taken, body weight and height were measured and body mass index (BMI) was calculated. Serum MCP-1 was determine by using ELISA technique (Elabscience Biotechnology Co. Japan). As well as, human Fetuin -A and IL-6 determine by ELISA kit (RayBiotech, USA).

For comparison, thirty apparently healthy subjects who were matched for age, weight, and BMI $[\mathrm{n}=30 ;$ age $=30.5 \pm 3.77$ (years); $\mathrm{BMI}=27.13 \pm 2.13(\mathrm{~kg} / \mathrm{m} 2)$; mean $\pm \mathrm{SD}]$ the control subjects do not suffer from any disease and not taking any medication.

\section{Statistical Analysis}

Statistical analysis was performed using SPSS-21 (Statistical Packages for Social Sciences- version 21). Unpaired t-test was used to assess significant difference between means. $\mathrm{P}<0.05$ was considered statistically significant. Receiver operation characteristic method (ROC curve) was performed by MedCalc -12 program(IBM corp 2012).

\section{Results and Discussion}

The prevalence of anti-H.pylori CagA IgG antibodies in patients group $(78.3 \pm 9.8 \mathrm{U} / \mathrm{ml})$ significantly higher $(<0.0001)$ than healthy subjects group $(4.2 \pm 2.8 \mathrm{U} / \mathrm{ml})$, while there were no significant differences between patients and healthy groups in the anthropometric measurements [weight (83.3 $\pm 6,82.2 \pm 6.4$ respectively) and height $(172.3 \pm 4.6,174.1 \pm 5.27$ respectively)], table (1).

H.pylori was capable with a significant 
differences in the inflammatory mediators (fetiun-A, MCP-1 and IL-6), as shown in table 2 .

Fetuin A levels were very highly significant lower $(\mathrm{P}<0.0001)$ in patients group when compared to healthy subjects group (29.53 \pm 5.25 vs. $53.45 \pm 8.37$ )

This was contrary to the MCP-1 levels which significantly increased $(\mathrm{P}<0.0001)$ in patients group (48.79 \pm 6.03 compared to control group (37.02 \pm 6.85$)$, figure (2).

The mean of IL-6 also shown highly significant difference $(\mathrm{P}<0.0001)$ in patients group when compared to healthy control

To find the sensitivity and specificity for each mediator, the receiver operation characteristic was done but it cannot be applied only in the MCP-1 because of the lack in overlap for the results except for the results of MCP-1.

In the current study, there was a positive correlation between MCP-1 and IL-6, as shown in table(3).

The effect of body weight also studied in the present study by divided the patients group to subgroups according to the values of BMIP (as Patient/optimal $\leq 1$ and Patient/overweight $>1$ ) as shown in table (4)

BMI Prime, a simple modification of the BMI system, is the ratio of actual BMI to upper limit BMI (currently defined at BMI 25). As defined, BMI Prime is also the ratio of body weight to upper body-weight limit, calculated at BMI 25. Since it is the ratio of two separate BMI values, BMI Prime is a dimensionless number without associated units. Individuals with BMI Prime less than 0.74 are underweight; those with between 0.74 and 1.00 have optimal weight; and those at 1.00 or greater are overweight. BMI Prime is useful clinically because individuals can tell, at a glance, by what percentage they deviate from their upper weight limits. For instance, a person with BMI 34 has a BMI Prime of 34/25 = 1.36, and is $36 \%$ over his or her upper mass limit.

Table above shows the multiple comparisons among three groups. 1 vs 2,1 vs 3 and 2 vs 3 . In this analysis we found that the two groups (Patient/optimal weight and overweight) did not differ in all parameters. In other words, it means that the BbodiesMIP has no effect on these parameters.

The prevalence of anti-H.pylori CagA Ig Gantibodies in patient group significantly higher $(<0.0001)$ than healthy subjects groups, a proportion similar to that reported also in Africa(Sanz-Pelaez et al., 2008,Smithsi et al2002). There is no significantly significant association with CagAIg positivity and age agreement with (Alsharipours et al., 2014). The current study found increase significantly IL-6 levels (Table2) agreed with (Hiroke Nakagawa et al.,2015) who found that serum IL-6 level was significantly among $H$.pylori infected in adult Japanese. Other study shown that H.pylori infection is associated with increased IL- 6 and TNF- $\alpha$ production within the gastric mucosa (Jamshid Vafaeimanesh et al., 2014).

Fetuin A is anti inflammatory mediator that participate in macrophage deactivation specially fetuin $\mathrm{A}$, enhance the cellular uptake of cationic inhibitors of proinflammatory cytokines synthesis by macrophage, thus preventing the morbid sequeleae of infection that result from over production of pro-inflammatory cytokines (Ombrellion M et al., 2001). 
Table.1 The Clinical Characteristics of H.pylori Infected Patients Compared to Control Group

\begin{tabular}{|ll|c|c|c|c|c|}
\hline & & $\mathrm{N}$ & Mean & Std. Deviation & Std. Error Mean & $\mathrm{P}$ \\
\hline \multirow{2}{*}{ Age } & Control & 30 & 30.53 & 3.77 & 0.68 & 0.36 \\
& Patient & 60 & 31.44 & 3.96 & 0.73 & \\
\hline \multirow{2}{*}{ Weight } & Control & 30 & 82.20 & 6.46 & 1.17 & 0.49 \\
& Patient & 60 & 83.31 & 6.03 & 0.96 & 0.17 \\
\multirow{2}{*}{ Height } & Control & 30 & 174.13 & 5.27 & 0.86 & $<0.0001$ \\
& Patient & 60 & 172.34 & 4.63 & 0.51 & \\
\hline \multirow{2}{*}{ CagAIgG } & Control & 30 & 4.28 & 2.80 & 1.82 & \\
& Patient & 60 & 78.36 & 9.82 & &
\end{tabular}

Table.2 The Immunological Markers in Patients vs. Control Group

\begin{tabular}{|ll|c|c|c|c|c|}
\hline & & $\mathrm{N}$ & Mean & Std. Deviation & Std. Error Mean & $\mathrm{P}$ \\
\hline \multirow{2}{*}{ Fetuin } & Control & 30 & 53.45 & 8.37 & 1.52 & $<0.0001$ \\
& Patient & 60 & 29.53 & 5.25 & 0.97 & \\
\multirow{2}{*}{ MCP1 } & Control & 30 & 37.02 & 6.85 & 1.25 & $<0.0001$ \\
& Patient & 60 & 48.79 & 6.03 & 1.12 & $<0.0001$ \\
\multirow{2}{*}{ IL6 } & Control & 30 & 4.35 & 1.16 & 0.21 & \\
& Patient & 60 & 9.25 & 1.96 & 0.36 & \\
\hline
\end{tabular}

Table.3 The Correlations Between Studied Parameters in Patients Group

\begin{tabular}{|c|c|c|c|c|c|c|c|}
\hline & & $\mathrm{Wt}$ & Heigh & $\begin{array}{c}\text { Cag-A- } \\
\text { IgG }\end{array}$ & Fetuin-A & MCP-1 & IL-6 \\
\hline \multirow{4}{*}{ Age } & Pearson Correlation & $.703^{* *}$ & $.438^{*}$ & -.252 & .010 & -.079 & $-.015-$ \\
\hline & Sig. (2-tailed) & .000 & .017 & .187 & .960 & .684 & .938 \\
\hline & $\mathrm{N}$ & 60 & 60 & 60 & 60 & 60 & 60 \\
\hline & Pearson Correlation & 1 & $.756^{* *}$ & .134 & .145 & $-.071-$ & $-.017-$ \\
\hline \multirow[t]{3}{*}{$\mathrm{Wt}$} & Sig. (2-tailed) & & .000 & .489 & .453 & .714 & .931 \\
\hline & $\mathrm{N}$ & & 60 & 60 & 60 & 60 & 60 \\
\hline & Pearson Correlation & & 1 & .212 & .029 & .131 & $-.052-$ \\
\hline \multirow{2}{*}{ Heigh } & Sig. (2-tailed) & & & 271 & 881 & .498 & .790 \\
\hline & & & & 60 & 60 & 60 & 60 \\
\hline & Pearson Correlation & & & 1 & .098 & .084 & .075 \\
\hline $\mathrm{Iag}$ & Sig. (2-tailed) & & & & .614 & .666 & 697 \\
\hline & & & & & 60 & 60 & 60 \\
\hline & Pearson Correlation & & & & 1 & $-.152-$ & .067 \\
\hline Fetuin-A & Sig. (2-tailed) & & & & & .431 & .731 \\
\hline & & & & & & 60 & 60 \\
\hline & Pearson Correlation & & & & & 1 & $.758^{* *}$ \\
\hline MCP-1 & Sig. (2-tailed) & & & & & & .000 \\
\hline & & & & & & & 60 \\
\hline & Pearson Correlation & & & & & & 1 \\
\hline IL-6 & Sig. (2-tailed) & & & & & & \\
\hline & $\mathrm{N}$ & & & & & & \\
\hline
\end{tabular}


Table.4 Studied Parameters in the Subgroups

Descriptives

\begin{tabular}{|c|c|c|c|c|c|c|c|c|c|}
\hline & \multirow[t]{2}{*}{$\mathrm{N}$} & \multirow[t]{2}{*}{ Mean } & \multirow[t]{2}{*}{$\begin{array}{c}\text { Std. } \\
\text { Deviation }\end{array}$} & \multirow[t]{2}{*}{ Std. Error } & \multicolumn{2}{|c|}{$\begin{array}{l}95 \% \text { Confidence } \\
\text { Interval for Mean }\end{array}$} & \multirow[t]{2}{*}{ Min. } & \multirow[t]{2}{*}{ Max. } \\
\hline & & & & & & $\begin{array}{l}\text { Lower } \\
\text { Bound }\end{array}$ & $\begin{array}{l}\text { Upper } \\
\text { Bound }\end{array}$ & & \\
\hline \multirow{5}{*}{ Age } & Control & 30 & 30.5333 & 3.77591 & .68938 & 29.1234 & 31.9433 & 25.00 & 41.00 \\
\hline & Patient/optimal & 14 & 28.1429 & 2.60951 & .98630 & 25.7295 & 30.5562 & 25.00 & 32.00 \\
\hline & $\begin{array}{l}\text { Patient/overweig } \\
\text { ht }\end{array}$ & 46 & 32.5000 & 3.76386 & .80246 & 30.8312 & 34.1688 & 25.00 & 41.00 \\
\hline & Total & 90 & 30.9831 & 3.86180 & .50276 & 29.9767 & 31.9894 & 25.00 & 41.00 \\
\hline & Control & 30 & 4.2867 & 2.80304 & .51176 & 3.2400 & 5.3333 & 1.50 & 12.10 \\
\hline \multirow{3}{*}{$\begin{array}{l}\text { CagA } \\
\text { IgG }\end{array}$} & Patient/optimal & 14 & 76.6000 & 6.23538 & 2.35675 & 70.8332 & 82.3668 & 67.00 & 86.00 \\
\hline & $\begin{array}{l}\text { Patient/overweig } \\
\text { ht }\end{array}$ & 46 & 78.9227 & 10.78685 & 2.29976 & 74.1401 & 83.7053 & 43.00 & 94.00 \\
\hline & Total & 90 & 40.6966 & 38.02125 & 4.94995 & 30.7882 & 50.6050 & 1.50 & 94.00 \\
\hline \multirow[b]{3}{*}{$\begin{array}{l}\text { Fetui } \\
\mathrm{n}\end{array}$} & Control & 30 & 53.4500 & 8.37190 & 1.52849 & 50.3239 & 56.5761 & 39.20 & 76.80 \\
\hline & Patient/optimal & 14 & 28.4286 & 6.14457 & 2.32243 & 22.7458 & 34.1113 & 19.60 & 37.40 \\
\hline & $\begin{array}{l}\text { Patient/overweig } \\
\text { ht }\end{array}$ & 46 & 29.8909 & 5.04654 & 1.07593 & 27.6534 & 32.1284 & 21.00 & 39.00 \\
\hline \multirow{4}{*}{$\begin{array}{l}\mathrm{MCP} \\
1\end{array}$} & Total & 90 & 41.6966 & 13.91893 & 1.81209 & 38.0693 & 45.3239 & 19.60 & 76.80 \\
\hline & Control & 30 & 37.0200 & 6.85527 & 1.25160 & 34.4602 & 39.5798 & 22.50 & 48.20 \\
\hline & Patient/optimal & 7 & 50.0429 & 5.86056 & 2.21508 & 44.6227 & 55.4630 & 39.60 & 55.40 \\
\hline & $\begin{array}{l}\text { Patient/overweig } \\
\text { ht }\end{array}$ & 22 & 48.4000 & 6.17337 & 1.31617 & 45.6629 & 51.1371 & 41.20 & 66.30 \\
\hline \multirow[b]{4}{*}{ IL6 } & Total & 59 & 42.8085 & 8.73817 & 1.13761 & 40.5313 & 45.0857 & 22.50 & 66.30 \\
\hline & Control & 30 & 4.3533 & 1.16285 & .21231 & 3.9191 & 4.7876 & .70 & 6.20 \\
\hline & Patient/optimal & 7 & 8.7143 & 2.20940 & .83507 & 6.6709 & 10.7576 & 6.30 & 11.40 \\
\hline & $\begin{array}{l}\text { Patient/overweig } \\
\text { ht }\end{array}$ & 22 & 9.4227 & 1.90586 & .40633 & 8.5777 & 10.2677 & 7.20 & 13.30 \\
\hline \multirow{4}{*}{ BMI } & Total & 59 & 6.7610 & 2.93980 & .38273 & 5.9949 & 7.5271 & .70 & 13.30 \\
\hline & Control & 30 & 27.1347 & 2.13247 & .38933 & 26.3384 & 27.9309 & 22.98 & 31.16 \\
\hline & Patient/optimal & 7 & 26.3571 & .82202 & .31070 & 25.5969 & 27.1174 & 24.91 & 26.96 \\
\hline & $\begin{array}{l}\text { Patient/overweig } \\
\text { ht }\end{array}$ & 22 & 28.5600 & 1.00762 & .21483 & 28.1132 & 29.0068 & 27.36 & 31.10 \\
\hline
\end{tabular}


Table.5 The Multiple Comparisons among Three Groups

Multiple Comparisons

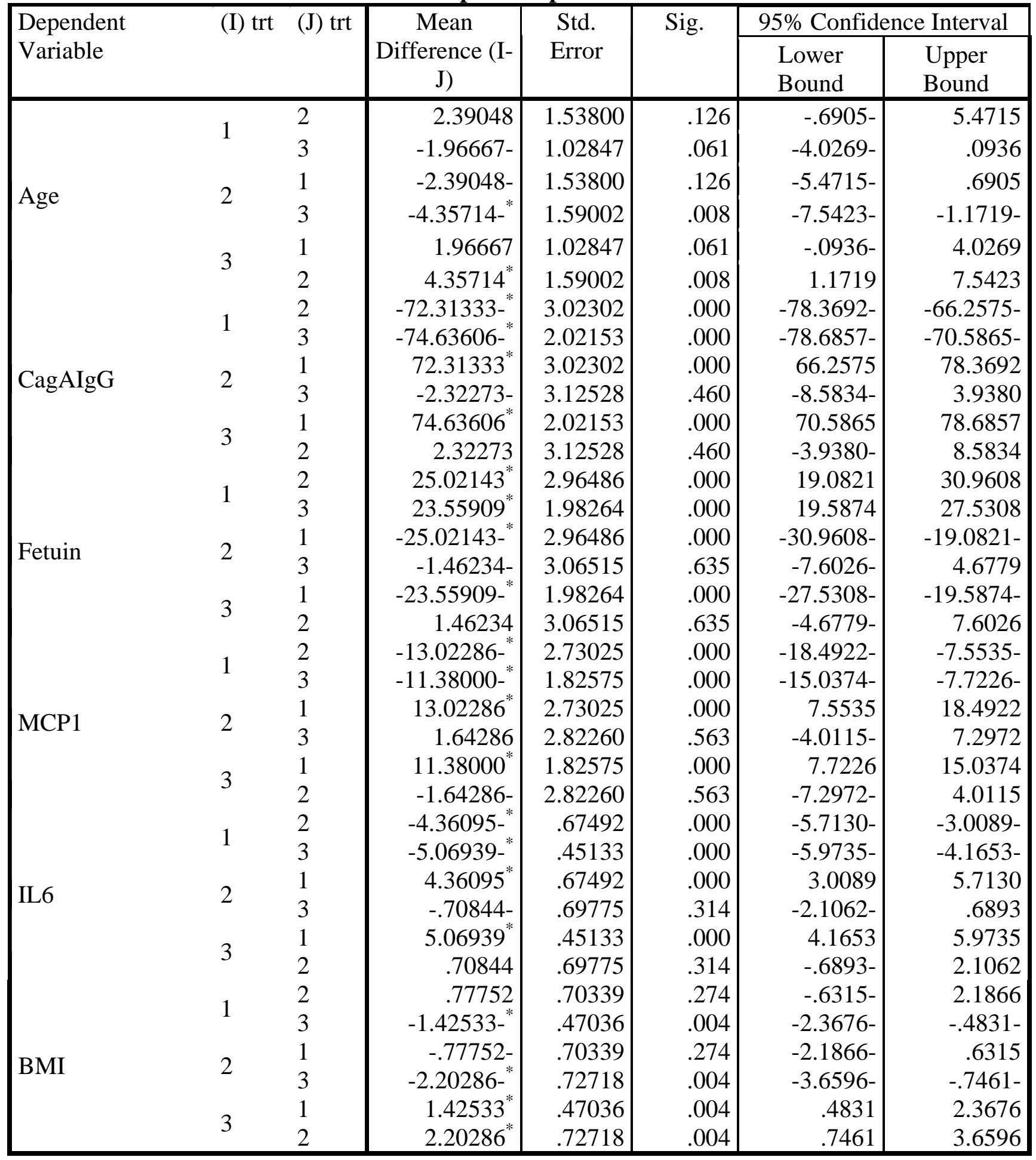

*. The mean difference is significant at the 0.05 level 
Figure.1 Mean of Fetuin A in Patient and Control Groups

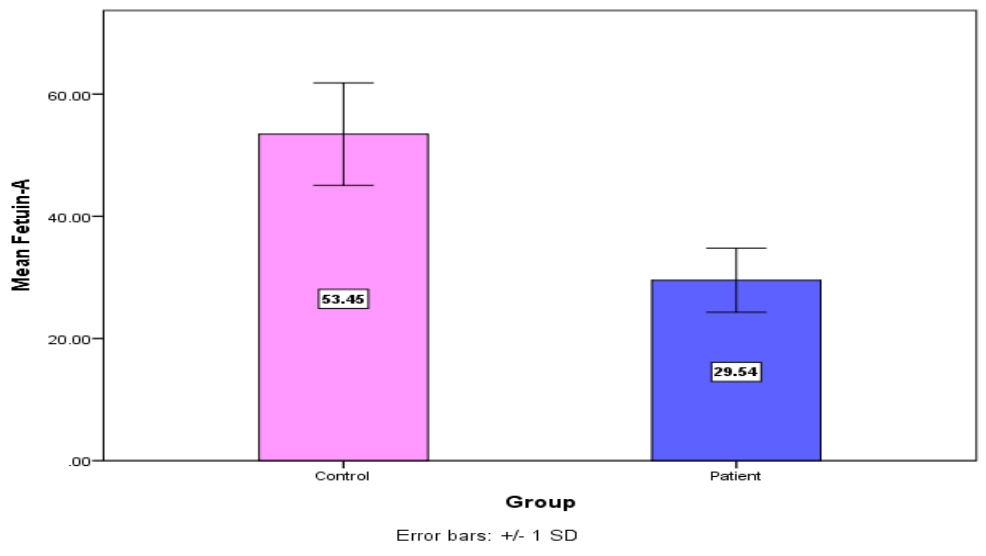

Figure.2 Mean of MCP-1 in Patients and Controls Groups

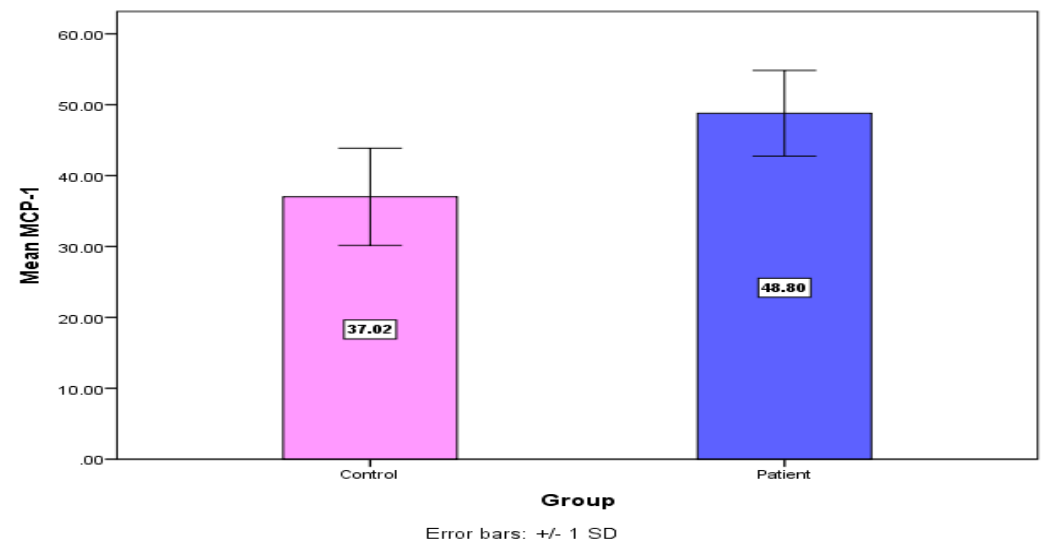

Figure.3 Mean of MCP-1 in Patients and Controls Groups

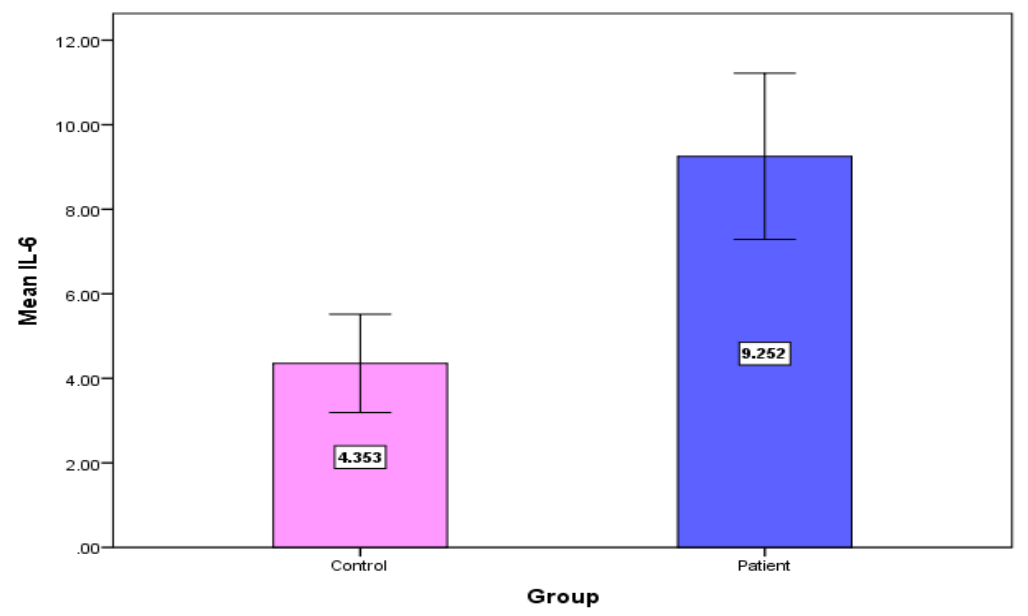


Figure.4 Receiver Operator Curve Analysis for the Investigated Parameters H.pylori Patients and Controls

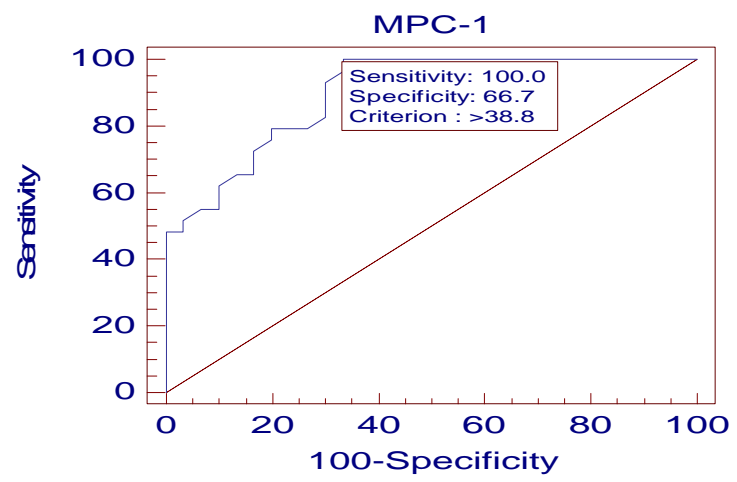

\begin{tabular}{|l|r|}
\hline Area under the ROC curve (AUC) & 0.898 \\
\hline Standard Error & \\
\hline $95 \%$ Confidence interval & \\
\hline z statistic & 0.0383 \\
\hline Significance level P (Area=0.5) & 0.792 to 0.962 \\
\hline
\end{tabular}

Fetuin A increase significantly in the current study (Fig1,2) and this finding in agreed with (Kebapiclar 2010) Who reported significant increase in anti-inflammatory markers such as Fetuin A. MCP1 to be higher in H.pylori positive versa agreed with (Nomura et al., 2004). In the current study, there was appositive correlation between MCP1 and,as shown in (Table 3). To our knowledge, there have been no reports for the correlation between MCP1, fetuin A and IL6 in Iraq. To evaluate infurther studies the molecular epidemiology of H.pylori infection in the general population.

In conclusion, MCP1was found to be significantly elevated in patients group versus the control group, also there was a significant difference in IL-6 level in H.pylori +ve versus healthy group. Fetuin A was found to be high in pateints group when compared to healthy subjects and there positive correlation between IL-6 and MCP1.

\section{References}

A.M.Hennige, H. Staiger, C. Wick. 2008. Fetuin A induces cytokine expression and suppresses adiponectin production plos one, vol3.ithectio.

Afsharipours NazariR, Douragnim.2014. Seroprevalence of anti H.pylori and anti cytotoxin. Antibodies among healthy, individual, in cer of Iran. Iran. J. Basic. Med. sci., 17(8):547-5.

Amine, Talebi Abadi.2014. Helicobacter pylori in Iran:Anew perspective. Journal of Jastroenterology and Hepatology. Research., 13(8):19811185.

Arabi MH, AlvaniS and Ehtera. 2010 H.Lipid profle in subjects with H.pylori in. fection. Iran. J. Path.,5:199ma-203.

Crabtree JE. 1998. Role of cytokines in pathogenesis of H.pylori induced mucosal damage. Dig. Dis Mitsula., Yci.43:465-555. 
Fischer W.PrasslS,HansR.2009. Virulnce mechanisims, and persistence stragies of the human gastric pathogen H.pyAlori:curr T. P. Microbiol. Immunol.,337:129-71.

Hiroko Nakagawa,Takashi Tamur,Yoko Miusuda, Yu suyuki Goto,Yoshikazu Kumiya,Takuaaki Kondo,Kenji Wakai and Nobuyuki Hamajian. 2013. Significant association between serum IL-6 and H.pylori antibody level among H.pylori positive Japanese adult. Mediators of inflammation.

IBM Corp.Released 2012. IBM SPSS Sttistics for Windows, Version21.0 Armonk,NY:IBM Corp Medcalc for windows, version12.5(MedCalc soft ware, Ostend,Belgium).

Jamshid Vafaeimanesh, Mahmoud Parham, Mohammadreza Seyyedmajidi, and Mohammad Bagherzadeh. Helicobacter pylori Infection and Insulin Resistance in Diabetic and Nondiabetic Population. The Scientific World Journal.Volume 2014 (10); 534-41.

Kebapiclar L,Bilgori O,Centiakaga E, Akyol M, Bilgisf, BozkyaG 2010. The effect of H.pylori eradication on macrophage migration inhibitory factor,c. reactive protein and Fetuin A aleveals Clinics(Sao Paulo)65:799-802.

kolier CM, Nelson Eb,Cohen CD, Horek R,SchlondorffD.NelonpJ.2001. Biol chemokine- induced secretion of gclatinace $\mathrm{B}$ in primary human monocyte .ki GotoBiol Chem,3821405-10.
Kopafa, sHedagatolla, Shrzad.2015. Mucosal interleukin 21-m RNA expression level is high in patient witH.pylori and associated with the severity of gastritis.Clinical. immunology.,40(1):61-67.

Nomura S,Inan,KanazMawas.2004.The effect of H.pylori eradication on chemokine production in patient with immune thrombo cytopenic purpura.Eur.J. Haematol.,72:304-305.

Ombrellion $\mathrm{M}$, WangH, YangH, ZhangM,Vishnubhakelcat JFrazerA. 2001.FetuinA,anegative acute phace protein attenuate TNF synthesis and the innate inflammatory response to carrayeenan. Shock.,15:181-5.

San-Pelaez O,Santana. Roriguezt, Maroto.AA.2008.H.pylori and CagA. Seroprevalence alence sub-Sabara inmegrants recentllyarrised to Gram conari(spain).Scand. J.infect. Dis.,2008:40:756-758.

SmithLSI,Kirsch GOyedeji Ks.2002.Prevalence of H.pylori vaCagA in sub Agenotypes in Nigeria patient with dudenum ulcer disease. J.Med. microbia1.,51:851-854.

Zandi F,Shirzad H,Bagheri N,AhmadiA, Azadeganf,Gharibi.2013.Evalution of the IL-17A andIL-17F genes polymorism In Iranian dyspeptic patients.Life.sci., 10(125):544-51.

\section{How to cite this article:}

Thamer Mutlag Jasim. 2016. Evaluation of Novel Immunological Mediator in Patients With Helicobacter pylori in Baghdad City, Iraq. Int.J.Curr.Microbiol.App.Sci. 5(1): 1-9. doi: http://dx.doi.org/10.20546/ijcmas.2016.51001, 